\title{
Research into English Education Strategies
}

\author{
Deng Yan \\ Foreign Languages Department,Xiangnan University
}

\begin{abstract}
Language is one of the most important communication tools in human society. With the globalization of economy and the continuous improvement of English education in our country, the heat of the whole nation is increasing. Under the impact of international multi culture, the cultural atmosphere of learning English has gradually formed in China. English teaching and learning has its own unique rules and strategies, but the past research is to explore the general meaning, its theoretical and practical significance are not enough attention. This article through the collection of information, a comprehensive understanding of English education status and related results, summarized and draw useful experience. Hope that through the study of English education strategy in order to get the solution to the problem. Try to improve English education in school English education platform.
\end{abstract}

Keywords-English education; Strategy; Interaction at class; Interest

\section{INTRODUCTION}

The world is in the special period of social information and economic globalization, language is the most important information carrier of human society, has become an indispensable tool in our daily life. As one of the most widely used languages in the world, English has become an important tool for international communication and cultural exchange. It is also an important link for China to better understand China. English education in improving the overall national literacy, but also to promote the development of China's innovation and cross cultural talents, enhance the international competitiveness of our country. In short, the students in our country if they can master English well, in order to help the students themselves to achieve a multi learning goal, but also extremely beneficial to our country in a better position to integrate into the world.

The main content of this paper is discussion about the implementation of the strategy of English education in several major problems, such as research strategies of situational teaching and learning with constructive strategies, the use of cross cultural training strategy so that English education, English learning obtain feasible theoretical guidance. On the basis of previous studies, a rational analysis of English education should be conducted in order to find out the theoretical level which should be possessed by the English language teaching.

\section{SIGNIFICANCE OF ENGLISH EDUCATION STRATEGY}

This will help avoid the blindness of English education. Do anything to pay attention to strategy, English learning is no exception. The most intuitive is reflected in preschool children and children's English education. The results show that the use of effective English education strategy, in a large margin to improve foreign language learning, but also improve the learning effect and quality, reduce the blindness of education.

This is conducive to promoting the penetration and research of foreign cultures. This is particularly prominent in the school's English based education. The process of learning the language is also a process of learning culture, and the process of receiving a language education is also a process of cultural education. As the trend of the international language are becoming more and more obvious, especially in the reform and opening up and the continuous expansion of foreign exchanges and cooperation in the context of the growing demand for foreign language talents, but also put forward new higher requirements.

This is conducive to promoting the penetration and research of foreign cultures. This is particularly prominent in the school's English based education. The process of learning the language is also a process of learning culture, and the process of receiving a language education is also a process of cultural education. As the trend of the international language are becoming more and more obvious, especially in the reform and opening up and the 
continuous expansion of foreign exchanges and cooperation in the context of the growing demand for foreign language talents, but also put forward new higher requirements.

\section{PROBLEMS IN ENGLISH EDUCATION}

\section{A. Spoon-Feed Education}

In the traditional way of English learning, students always remember words and grammar and do a lot of questions... Not only the teacher is tired in teaching, but children are also very disgusted at the "spoon-feed" education with no interest in learning, but they are only in order to attend test and examination. China to "test scores, research characteristics of English education, binding the child's growth, formed a strong orientation error, in the future growth of the road, and children are forced to learning English, for" research "and to learn English, standing on the starting line of the" dumb English "or" deaf English ". That, after the real work on the job, can not be flexible application of knowledge, English communication ability is poor, can not meet the actual needs of the community.

\section{B. Unreasonable Exam Papers}

Even after learning English for more than ten years, students cannot understand a piece of English news and in the end, most Chinese students are just like blind men touching the elephants in learning English. They know each part, but they do not know how to gather them together. Textbook to teach good English article is split into a sentence, a word a word test, Chinese students can test out to synthesize an eloquent article, unintelligible. As a language exchange of English has been lost in the test scores. Don't blame Chinese students being dumbfounded after learning English for more than ten years.

\section{STRATEGIES FOR ENGLISH EDUCATION ClASS}

According to the above problems, the following class learning strategies are proposed in this paper.

\section{A. Ladder Positioning}

English compulsory education stage from the third grade began, in English education process up to ten years, with the age of the students and academic phase change, educational content and methods of English but also with a major change in the primary stage the main emphasize the development of interest, but also focuses on secondary school-based compaction, and college learning English entered the advanced stage, this time will be even more emphasis on the syntax of the language, as well as the construction of Anglo-American culture, research and learning. Therefore, phased ladder positioning strategy becomes precious.

\section{B. Creating Situations}

Situational teaching is teaching students an ability to develop teaching methods of students' intelligence. Specifically refers to teachers in the teaching process in order to achieve the intended purpose of teaching, from teaching needs, create or adapt and create content and teaching scene, the atmosphere, in order to stimulate students' enthusiasm for learning and emotional experience, helping students teaching in a pleasant atmosphere rapid acceptance of new knowledge, to achieve the ultimate goal of the learning process in special situations. This teaching strategy can be flexible knowledge into vivid situation among students can lead to great interest and curiosity, so do the music school and eager to learn.

\section{Cultivating Cross-Cultural Awareness}

"Cross-cultural Awareness" is a foreign culture and their own culture and sensitivity of the dissimilarity of the same place, as well as to adjust itself to the use of English language understanding and awareness of consciousness according to a foreign culture. Visible, if, as in the usual teaching English teachers do not attach importance to cross-cultural awareness training for students, it will only make the teaching process to become a pure single accumulation of knowledge, but missing on the language of the soul - understanding the culture, from a in terms of the kinds of consciousness, and this teaching is a sad failure.

\section{CONCLUSION}

The world today is at a special period undergoing social information and economic globalization. As the most important information carrier, language has already become an indispensable tool in all aspects of our life. China, as an important country in the world, should bear 
the important historical mission and international responsibility. An important tool for English as one of the world's most widely used language, have become international exchanges and cultural exchanges, but also to make China a better world, to make the world a better understanding of an important link in China.

Therefore, English education deserves our attention, and based on discussing the theoretical significance and practical importance of applying strategies to English education and proposes three effective strategies: ladder positioning, creating situation and cultivating cross-cultural awareness. Finally, it targets at allowing English educators and English learners to obtain feasible theoretical guidance.

\section{REFERENCES}

[1] [1] Thornton P, Houser C. Using mobile phones in English education in Japan [J]. Journal of Computer Assisted Learning, 2005, 21(3):217-228.

[2] [2] Daly J A, Hexane A. Statistical Power in Research in English Education. [J]. Research in the Teaching of English, 1983, 17(2):157-164.
[3] [3] Grabill, J. T., \& Hicks, T. (2005). Multiliteracies meet methods: the case for digital writing in english education. English Education, 37(4), 301-311.

[4] [4] Armytage W H G. Four hundred years of English education[M]// At the University Press, 1970.

[5] [5]Swenson, J., et al. "Extending the Conversation: New Technologies, New Literacies, and English Education.." English Education 38.4(2006):351-369.

[6] [6] Sperling, Melanie, and A. Dipardo. "English Education Research and Classroom Practice: New Directions for New Times." Review of Research in Education 32.1(2008):62-108.

[7] [7]Barnard H C, Armytage W H G. Four Hundred Years of English Education[J]. History of Education Quarterly, 1965, 13.

[8] [8] Machin, Stephen, and S. Mcnally. "The Evaluation of English Education Policies." National Institute Economic Review 219.1(2012):R15-R25.

[9] [9] Mchatton P A, Daniel P L. Co-Teaching at the Pre-Service Level: Special Education Majors Collaborate with English Education Majors[J]. Teacher Education \& Special Education the Journal of the Teacher Education Division of the Council for Exceptional Children, 2008, 31(2):118-131.

[10] [10] Jo, Seongja. "English education and teacher education in South Korea." Journal of Education for Teaching 34.4(2009):131-141.

[11] [11]Yagelski R P. Stasis and Change: English Education and the Crisis of Sustainability.[J]. English Education, 2005, 37(4):262-271.

[12] [12]Machin S, Mcnally S. The Evaluation of English Education Policies[J]. National Institute Economic Review, 2012, 219(1):R15-R25. 